Island Studies Journal, Vol. 8, No.1, 2013, pp. 3-8

\title{
Guest Editorial Introduction
}

\section{The Idea of the Archipelago: Contemplating Island Relations}

\author{
Elaine Stratford \\ University of Tasmania \\ Australia \\ Elaine.Stratford@utas.edu.au
}

\begin{abstract}
Creative, innovative, and timely research on islands and island futures is warranted and pressing, not least because island(er)s are poorly served by established tropes of them as subordinate to continents or mainlands. Opportunities exist to provide a more thoroughgoing account of island life and island relations, and the seven papers in this special issue address that task. In works that consider islands in the Timor Sea, the Caribbean, the Pacific, Atlantic and Southern Oceans, and that span several different disciplinary frames-archival-historical, critical theoretical, literary, cultural, geopolitical, sociological and artistic - these papers evidence both the diversity of approach to thinking with the archipelago, and numerous points in common. Among the latter is an understanding that island relations are built on connection, assemblage, mobility, and multiplicity, and a commitment to critically examine the ways in which these entanglements affect and give effect to island life. The models of island relationality brought to light by this collective focus on the archipelago reveal new and diverse connections of island peoples with their physical and cultural environments, and with the world beyond; create spaces for growing resilience, association and engagement; and invite further study.
\end{abstract}

Keywords: archipelago; assemblage; connection; island relations; mobility; multiplicity

(C) 2013 Institute of Island Studies, University of Prince Edward Island, Canada

Nominally a group of islands, more properly a sea studded with islands, and originally 'the chief sea' that more commonly is known as the Aegean, the archipelago is a geographical form that invites significant productive thinking about island relations. I have been pondering why such labours to rethink island relations anew might matter, doing so most concertedly by working alongside colleagues Elizabeth McMahon, Godfrey Baldacchino, Steve Royle, and Carol Farbotko. Together, we have put the case that creative, innovative, and timely research on islands and island futures is urgently needed. In the face of challenging changes at various scales of impact, we suggest that island peoples and places are not served well by prevalent ideas of them as remote and dependent on oft-distant mainlands. Indeed, these tropes hamper more complete and nuanced understandings of the island condition and island prospects. Alternatively, we surmise, the idea of the archipelago suggests relations built on connection, assemblage, mobility, and multiplicity.

For centuries, island worlds have been positioned as geographical entities mostly isolated and unmappable - 'other spaces' that need to be occupied, conquered, and colonized. Yet, archipelagos were connected by nautical trade routes long before European interventions. Indeed, for Elizabeth DeLoughrey (2007), geography is an appropriate starting point to explore 


\section{E. Stratford}

land/sea relationships that favoured complex patterns of migration and settlement, and that exemplify the idea that islands are the open subjects of 'transoceanic imaginaries'. So, too, is geography an appropriate starting point to explore mainland/island and island/island relations, and the archipelago may be a useful material and theoretical tool in such labours. As Elizabeth McMahon has suggested to me in conversation, thinking with the archipelago may reveal multiple emancipatory narratives that enunciate exceptions to colonizing grammars of empire that rendered islands remote, isolated and backward. Thinking with the archipelago thus may also enable island scholars and others to radically recentre positive, mobile, nomadic geopolitical and cultural orderings between and among island(er)s.

This special set of papers focuses upon just such matters. Its genesis might also be read archipelagically for, in 2010, I found myself in conversation with colleague Dr Joseph Palis (North Carolina State University) on the island of Bornholm, Denmark, at a conference of the International Small Island Studies Association. There, Joseph and I talked about our mutual interest in positioning island geographies more visibly at annual meetings of the Association of American Geographers. Thus it was that at, on the archipelagic shores of Seattle at the AAG in 2011, with Arnd Holdschlag from the University of Hamburg, we brought together several presenters to focus on the theme Reframing islandness I: critical and discursive cartographies in island worlds. This inaugural day-long session engaged thirteen scholars, notably doctoral candidates and early career researchers, who are working on diverse geographies of the Galápagos Islands, the Solomons, the Bahamas, the Dominican Republic, New Zealand, and on island languages, island mobilities, island censuses, statistics, and place names, tropes of tropicality, and the cartographic impulse to map island places. Delighted at the response, we determined to organize a second session at the AAG Conference on the island of Manhattan in February 2012, entitled Reframing islandness II: thinking with the archipelago. The day's sessions attracted 24 speakers and a significant audience, attesting, we think, to the growing interest in island studies. It included two panel discussions: one on islands, arts and the geographical imagination; and another on Island enclaves, Baldacchino's (2010a) monograph on offshoring strategies, creative governance, and subnational island jurisdictions. Let me now turn to the papers from the conference that comprise this special issue.

In considering island movements as a means to think archipelagically, Jonathan Pugh starts from the premise that islands are deeply implicated in the contemplation of human nature and our place in the world. He then builds a compelling argument to show that inattention to the archipelago is problematic "because we live (increasingly) in a world of island-island movements and not static forms" both obvious and less apparent, among them, "wind turbine arrays, industrial oil and military constellations". Graciously (but not uncritically) building on Stratford et al. (2011), and setting the scene for the papers that follow in ways that will set agenda for new scholarship, Pugh asks "what does it mean to think with the archipelago?" His twin argument is that this labour will denaturalize how we think of space and place, and that it enables a focus on 'metamorphosis': "the adaptation and transformation of material, cultural and political practices through island movements". Building in new ways on work on the spatial turn (Pugh, 2009) and Caribbean islands (most recently, Pugh, 2012), he then applies his own critical reflections to post-colonial island movements, asking "how do Caribbean people struggle with and against the language that they have inherited, and is this language up to the task of effectively naming and renaming the New World that they inhabit?" For Pugh, the archipelago provides a framework of transfiguration rather than repetition, and "gives us another reason why we should not only think about, but with, islands". 
In a study demonstrating the ongoing value of the archive and of meticulous historical analysis of geographical dynamics, Anyaa Anim-Addo is concerned with the Caribbean and island-to-island movements and mappings that implicate the operations of the Royal Mail Steam Packet Company. I have already alluded to the importance of the idea of networks in archipelagic thinking, and for Anim-Addo a networked approach offers "a useful lens through which to analyse nineteenth-century steamship services"; it also provides "a theoretical intersection between networked approaches to empire and island studies". Indeed, and in ways that should influence the reconceptualization or refinement of such approaches, Anim-Addo suggests that thinking archipelagically enables a sharpening of analytical focus, such that certain "colonial priorities, imperatives and hierarchies that can appear flattened out through a networked approach" are brought to the fore. In Anim-Addo's work, such thinking has foregrounded "the relationship between the maritime service and mobilities in the Caribbean" (see also Anim-Addo, 2012). It has also demonstrated empirically how those charged with negotiating a transportation network within the Caribbean archipelago were forced to respond to various forms of connection and entanglement between and among islands, thus adding weight to earlier speculations advanced by Stratford et al. (2011). Anim-Addo is able to posit that "if the steamship network was a network in process ... part of this process was one of resolution between maritime links and archipelagic relations" and invites others to "develop a nuanced understanding of the significance of mobilities in colonial and postcolonial contexts".

Laurie Brinklow's paper focuses upon the rich artistic veins that may be tapped by dwelling in island place (see also Brinklow, 2012). Seeking to demonstrate how these variable landforms have captured the artistic imagination, Brinklow argues that archipelagos further intensify characteristics of island life such as "boundedness and connection, isolation and community". Her focus is upon the ways in which islandness gains expression among practising artists whom she describes as living "poles apart — on 'archipelagos' of the Canadian North Atlantic and the Great Southern Ocean". Brinklow's work draws upon in-depth and richly nuanced interviews with artists and writers in Newfoundland and Tasmania to contemplate "the nature of attachment and attraction to islands", using phenomenology to examine a range of other entanglements between and among islands. At the end of her paper, and on the basis of evidence that "artists on these islands can teach the world, about living with openness, with resilience, inclusivity, and fluidity", Brinklow conjures up Elizabeth DeLoughrey's (2001) work 'The litany of islands, the rosary of archipelagos'. She does so to remind readers that "archipelagos ... are a prayer for islands with stories being repeated over and over again; and they are the rosary: a metaphor for faith, and hope".

Metaphor is a central concern to Elizabeth McMahon in an essay that deploys the archipelago, a Western concept, in order to consider island to island relations in the Torres Strait between Australia and Papua New Guinea. McMahon has written extensively on islandAustralia (for example, McMahon, 2003, 2010); and here she continues to interrogate the "imaginary domain of story, in both its written and oral modes". Drawing on the "Stories under Tagai' project that formed part of one Torres Strait Cultural Festival, McMahon examines both traditional and modern stories of the islands using "Spivak's notions of planetarity and Bloch's concept of utopianism" to chart the relationships between two narratives: one entitled Wamin Ngurbum (Wami's Banana Tree), which "maps the interconnected concepts of ownership, land and sea"; the other from the novel Butterfly Song by Terri Janke, whose home is Thursday Island, which "establishes the interconnectedness of the human with the island home: its land and water, its life forms, its human culture". Intrinsically interesting though the stories are, 


\section{E. Stratford}

McMahon's larger concern is with demonstrating how Torres Strait literature and storytelling enable scholars to reconsider "relations of space and time and to acknowledge a spatial and temporal mobility running parallel to the circumscribed trajectories of late modernity". For her, these stories represent, in Deleuzian terms, a "world in process", confounding "divisions of land and sea, which are understood to be in dynamic flux", and inscribing a "profound and recurring image of inhabitation as synonymous with the elements of the planet itself", offering "an archipelagic capacity to sustain connection and meaning across land and water".

In different ways, the challenge of sustenance - of maintaining meaningful connections over distance, and especially over watery distances - concerns Carol Farbotko and Heather Lazrus in our joint paper on islands, emigration, sovereignty and climate change (see also Farbotko \& Lazrus, 2012; Stratford \& Langridge, 2012). We consider the utility of thinking with the archipelago by reference to conceptual labours already performed by Antonio BenítezRojo, Elizabeth McMahon, and Elizabeth DeLoughrey, and with respect to the Pacific atoll nation-state of Tuvalu. We specifically contemplate scenarios of forced emigration and the loss of territory and sovereignty in relation to fenua: how "a set of customary practices and territorial markers explains the biographical location of identity in place". We also examine Burkett's (2011) discussion of the 'nation ex-situ' as one possible remedy that may reframe how sovereignty is conceived. Our contention is that these conceptual and material resourcesarchipelago and fenua - invite consideration of mobility and connection, which are useful for unsettling Westphalian forms of sovereignty and territory and when accounting for the emotional geographies that attend climate change. In the final analysis, fenua facilitates the capacity to map identity to an island as a whole, enabling both place-based relations and mobility, multiplicity and interconnection; and the archipelago serves as a bridge, allowing for the movement of people, ideas, reforms and innovations.

Altogether different modes of movement are examined by Godfrey Baldacchino and Eduardo Costa Duarte Ferreira in a discussion of competing notions of diversity in archipelago tourism. Focusing upon transport logistics, official rhetoric and inter-island rivalry, Baldacchino and Ferreira start from the premise that archipelagic spaces are constituted by contending and competing geographies, not least among them those that form part of the fabric of multi-island tourism industries that encourage visitors "to explore and sample different island constituents" of a given territory. Paradoxically, however, this strategy "does not necessarily speak to the cultural and biogeographical forms of diversity that reside" in any archipelago. In seeking to understand this incongruity and its implications, Baldacchino and Ferreira rethink certain problems and challenges encountered in island tourism by deploying the archipelago anew, and then focus upon the case of the Azores, Portugal. Their analysis reveals a range of "inter-island rivalries and tourism marketing pitches, and the all too glaring gaps, differences and inconsistencies between these practices". They note the manner in which marketing tends to promote brand consolidation at the expense of diversity and authenticity (see also Baldacchino, 2010b), and propose that inter-island rivalry does not, in fact, seem to interfere with the proper promotion of the Azores as a tourist locale. Indeed, Baldacchino and Ferreira argue that "inter (and intra) archipelagic diversity" and especially that which resonates "more closely with political history and socio-cultural praxis" could reinforce the Azores' reputation as a premier tourism destination. In short, archipelagicity becomes a resource both in conceptual and material terms.

I mentioned above that our Manhattan meeting in 2012 involved a panel discussion on arts, islands and the geographical imagination. Donald Lawrence's contribution to that panel, 
formalized and expanded, furnishes the last paper in this special section on thinking with the archipelago. Lawrence's work considers the archipelago as a model of exchange and commerce - not in terms of tourism, as does the paper that precedes it - but as the meeting place of art, the geographical imagination and the map, itself a powerful tool to illumine the differences that exist in our individual and collective lives (see also Donald Lawrence Online Portfolio, nd) Specifically, Lawrence writes of two of his artistic projects at the junction of twin passions: art making and sea kayaking; these he describes as "constituting a vernacular, personally inscribed practice". The projects are Fiddle Reef Remembered (2006 and ongoing) and Kayak/Camera-Obscura (2010 and ongoing), and were based respectively in Victoria, Vancouver Island and Launceston, Tasmania. Of the former, Lawrence writes that when "considered on the largest of scales - the scale undertaken through my own, personal mapping - Fiddle Reef is an archipelago in miniature, one all but overlooked" until Lawrence reveals the delicate crenulations of the reef in his work. He also describes taking two "Klepper Aerius I folding sea kayaks of 1960-1970 vintage" to Tasmania for work that then featured in the Ten Days on the Island international biennial festival. There, he used one kayak as the floating island for a camera obscura, whose inverted images of water transportation, often so critically important for island people, also underscore the abiding search for connection.

Finally, let me return to thinking that is emerging in concert with colleagues Elizabeth McMahon, Godfrey Baldacchino, Steve Royle, and Carol Farbotko: If island futures are to be reconceived in ways that yield helpful scholarship, that influence policy formulation, and that inform transformative practices, research must be produced that considers how islanders creatively understand and use the interconnections between real and imagined renderings of island life. New work is coming to light by which islanders and island scholars are envisaging island relations anew, and that is being done, in part, in the pages of this and other journals such as Shima, the journal of the Small Island Cultural Research Initiative (for example, see Dawson, 2012 and Hayward 2012). Much still remains to be done to unsettle established understandings of the island as isolated and dependent, and therefore as vulnerable: particularly in times of testing change. In my view, the models of island relationality that will be brought to light by a collective and critical focus on the archipelago should reveal new and diverse connections of island peoples with their physical and cultural environments, and with the world beyond, and will create spaces for growing resilience, association and engagement.

\section{Acknowledgments}

Sincere thanks go to the authors for their commitment to this project; presenters at Reframing Islandness I and II; Joseph Palis and Arnd Holdschlag; those colleagues who provided feedback during the blind peer review process; and the editorial team at ISJ.

\section{References}

Anim-Addo, A. (2012). Place and mobilities in the maritime world: the Royal Steam Packet Company in the Caribbean, c. 1838 to 1914 . Doctoral dissertation, University of London. 


\section{E. Stratford}

Baldacchino, G. (2010). Island enclaves: offshoring strategies, creative governance, and subnational island jurisdictions. Montreal, QC: McGill-Queen's University Press.

Baldacchino, G. (2010). Island brands and 'the Island' as a brand: insights from immigrant entrepreneurs on Prince Edward Island. International Journal of Entrepreneurship and Small Business, 9(4), 378-393.

Brinklow, L. (2011). The proliferation of island studies. Griffith Review, 34, 1-6.

Burkett, M. (2011). The nation ex-situ: on climate change, deterritorialized nationhood and the post-climate era. Climate Law, 2(3), 345-374.

Dawson, H. (2012). Archaeology, aquapelagos and island studies. Shima: The International Journal of Research into Island Cultures, 6(1), 17-24.

DeLoughrey, E. (2001). The litany of islands, the rosary of archipelagoes: Caribbean and Pacific archipelagraphy. Ariel: A Review of International English Literature, 32(1), 2151.

DeLoughrey, E. (2007). Routes and roots: navigating Caribbean and Pacific island literatures. Honolulu, HI: University of Hawai'i Press.

Hayward, P. (2012). Aquapelagos and aquapelagic assemblages. Shima: International Journal of Research into Island Cultures, 6(1), 1-11.

Donald Lawrence Online Portfolio (no date) retrieved from http://www.donaldlawrence.ca/

Farbotko, C., \& Lazrus, H. (2012). The first climate refugees? Contesting global narratives of climate change in Tuvalu. Global Environmental Change, 22(2), 382-390.

McMahon, E. (2003). The gilded cage: from utopia to monad in Australia's island imaginary. In R. Edmond \& V. Smith (Eds.) Islands in history and representation (pp. 190-202). London: Routledge.

McMahon, E. (2010). Australia, the island continent: how contradictory geography shapes the national imaginary. Space and Culture, 13(2), 178-187.

Pugh, J. (2009). Viewpoint: What are the consequences of the 'spatial turn' for how we understand politics today? A proposed research agenda. Progress in Human Geography, 33(5), 579-586.

Pugh, J. (2012). Speaking without voice: participatory planning, acknowledgment, and latent subjectivity in Barbados. Annals of the Association of American Geographers, First Page Preview Online.

Stratford, E., \& Langridge, C. (2012). Critical artistic interventions into the geopolitical spaces of islands. Social and Cultural Geography, 13(7), 821-843.

Stratford, E., Baldacchino, G., McMahon, E., Farbotko, C., \& Harwood, A. (2011). Envisioning the archipelago. Island Studies Journal, 6(2), 113-130. 